\title{
Translation Quality on Words Containing Spelling, Punctuation and Grammatical Error
}

\author{
Trisakti Agriani*; M. R. Nababan; Djatmika Djatmika \\ Department of Linguistics, Universitas Sebelas Maret, Indonesia \\ Email: saktitititi@gmail.com
}

http://dx.doi.org/10.18415/ijmmu.v5i5.314

\begin{abstract}
This study aims to assess the translation quality in terms of accuracy, acceptability, and readability of words that contain spelling, punctuation and grammatical errors that represent the condition of Autism character in Flowers for Algernon novel by Daniel Keyes using an instrument from Nababan, Nuraeni, and Sumardiono (2012). This research uses qualitative descriptive method. Data collection is done through document analysis, questionnaire, and FGD. From 309 data found in the study, 303 data $(98.05 \%)$ were accurately translated and 6 data $(1.94 \%)$ were translated inaccurately. In terms of acceptability, 177 data $(57.28 \%)$ were acceptable, 126 data $(40.77 \%)$ were less acceptable and 6 data (1.94\%) were unacceptable. While for readability aspect, 285 data $(92,23 \%)$ were stated to have high readability, 18 data $(5.82 \%)$ had medium readability and 6 data $(1.94 \%)$ had low readability. The average score is 2.81 . This score indicates the translation has a good quality of accuracy, acceptability, and readability.
\end{abstract}

Keywords: Translation Quality; Spelling Error; Punctuation Error; Grammatical Error

\section{Introduction}

Nowadays, especially in globalization era, communication in many languages is very important. And of course, the method of communication is needed to apply the communication. But because of there are so many languages in all over the world, the communication become problem for them. The only solution of the problem in different language is through translation. Nida and Taber (1982: 12) state that, "Translating consisting of reproducing in the receptor language natural equivalent of the source language message, first in terms of the message and secondly in terms of style". From the Nida and Taber statements, there are two things in the translation process. The first is to produce a message that is commensurate with the source language, and the second is to produce a natural equivalence in terms of the language style. Based to the definition, translating means transfer the message from SL into TL. The message in TL should have the equivalence and closely meaning with the SL. In conclusion, meaning is more important than style in translation. Moreover, Nord (2005) defines the phenomenon as "the replacement of a representation of a text in one language by a representation of an equivalent text in a second language." Baker (2006: 77) defines equivalence as the relationship between a source text (ST) and a target text (TT) that has allowed the TT to be considered as a translation of the ST in the first place. 
Based to the definition, translating means transfer the message from SL into TL. The message in TL should have the equivalence and closely meaning with the SL. In conclusion, meaning is more important than style in translation.

A good translation has to transfer the message from source language to target language very well. The readers sometimes only read the translation product without paying attention to the translation quality. Translation quality assessment is very important for translation product. Translation quality assessment is an activity to give value to a translation product whether the product is having good quality or not. Assessing or criticizing a translation is not an easy matter because it needs an extraordinary ability (Nababan., 2003). The translation product is not always good. Sometimes there are many mistakes in the translation product when it is compared to the original one. Assessment towards translation quality focuses in three things namely accuracy, acceptability, and readability.

The quality of translation, it needs to have an assessment quality of translation. Assessment of translation quality determined to evaluation translations performed by professional translation. The assessment quality of translation results is defined by three aspects, namely accuracy, acceptability and readability (Nababan., Nuraeni and Sumardiono., 2012). The best translation is the translation with a high degree of accuracy, acceptability and readability. However, with a variety of considerations in practice it is sometimes difficult to produce perfect translations. Often translators are confronted with the choice to be more concerned with an aspect and slightly offer another aspect. That is why, that translation quality have to face this three aspects which are; 1) accuracy; 2) acceptability; and 3) readability.

\section{Accuracy}

According to (Nababan, Nuraeni and Sumardiono., 2012) accuracy is related to the correspondence of content or messages between Source language and Target language. Translated messages must be accurately conveyed, equally meaningful. In the source language contained the content or messages should not change, either by adding or reduce the content or messages. If in the target language add or reduce the content or messages is consider an attempt to betray the original writer and target reader. However, the addition (or) reduction that is not intended to reduce or adding information is a translation technique that can be use translator to address equivalent and easy to understood for the target reader.

Table 1 The instrument assessment of accuracy

\begin{tabular}{|c|c|c|}
\hline Category & Qualitative Parameter & Score \\
\hline Accurate & $\begin{array}{l}\text { Meaning of words, technical terms, phrase, clause, } \\
\text { sentence or source language text is accurately } \\
\text { transferred into the target language text. There is } \\
\text { no distortion of meaning. }\end{array}$ & 3 \\
\hline Less accurate & $\begin{array}{l}\text { Most of the meanings of words, technical terms, } \\
\text { phrases, clauses, sentences or source language } \\
\text { texts have been accurately transitioned into target } \\
\text { language. However, there is still distortion of } \\
\text { meaning or double translation of meaning or some } \\
\text { omitted meaning, disturbing the integrity of the } \\
\text { message. }\end{array}$ & 2 \\
\hline Not accurate & $\begin{array}{l}\text { Meaning of words, technical terms, phrases, } \\
\text { clauses, and sentences or source texts are not } \\
\text { accurately transferred in the target text or deleted. }\end{array}$ & 1 \\
\hline
\end{tabular}




\section{Acceptability}

Second, the aspect of acceptability refers to the appropriateness of translation to norms, rules and cultures that exist in the target language, both on the micro level and macro (Nababan., Nuraeni and Sumardiono., 2012). If the translation is not appropriate with binding norms and cultural norms in the target language, the results the translation was deemed unacceptable. If the translation does not match rules, norms and culture of the target language, then the translation would be not natural and rejected by the target audience.

Table 2 The instrument assessment of acceptance

\begin{tabular}{|c|c|c|}
\hline Category & Qualitative Parameter & Score \\
\hline Acceptable & $\begin{array}{l}\text { The translation is natural; familiarity of technical terms } \\
\text { to the reader; phrase, clause and sentence used } \\
\text { conform to the grammar of the target language } \\
\text { (Indonesian). }\end{array}$ & 3 \\
\hline $\begin{array}{l}\text { Less } \\
\text { acceptable }\end{array}$ & $\begin{array}{l}\text { In general the translation is natural; however, there are } \\
\text { some little mistakes or problems in using some } \\
\text { technical terms or occurrence of some grammatical } \\
\text { mistakes. }\end{array}$ & 2 \\
\hline $\begin{array}{l}\text { Not } \\
\text { acceptable }\end{array}$ & $\begin{array}{l}\text { The translation it not natural; unnecessary technical } \\
\text { terms or not even familiar to the reader; phrase, clause } \\
\text { and sentence used don't conform to grammar of the } \\
\text { target language (Indonesian). }\end{array}$ & 1 \\
\hline
\end{tabular}

\section{Readability}

The aspect of readability refers to the understanding of the target reader to the translation work. A translation should be able consider the rate at which the reader is translating (Nababan., 2008). An interpreter should be able to consider who will read the translation so that his translation can be adjusted. Here is the instrument of readability assessment.

Table 3 The instrument assessment of readability

\begin{tabular}{clc}
\hline Category & Qualitative Parameter & Score \\
\hline \multirow{3}{*}{ High } & $\begin{array}{l}\text { Words, technical terms, phrases, clauses, } \\
\text { sentences or subtitles can be easily } \\
\text { understand by the reader. }\end{array}$ & 3 \\
\hline Moderate & $\begin{array}{l}\text { Generally the translation can be understood } \\
\text { by the reader; but there are certain parts that } \\
\text { must be read more than once to understand } \\
\text { the translation. }\end{array}$ & \\
\hline Low & $\begin{array}{l}\text { The translation it not natural and } \\
\text { Translation is difficult for the reader to } \\
\text { understand. }\end{array}$ & \\
\hline
\end{tabular}


Spelling is an important aspect of language knowledge; it is a key functional component of writing. In other words, spelling is the key to both reading and writing of the language, therefore effective writing depends on effective spelling. Poor spelling can interfere with communication between the writer and the reader. (Smedley., 1983; Moseley., 1993; Brann., 1997; Willett., 2003). Ida (2006) states that unquestionably English spelling is a difficult and complex matter and learners around the world have difficulty getting the letters right. As stated by Fay (1971) English spelling is characterized by the inconsistencies of pronunciations, as well as by the discrepancies in the numbers and combinations of letters used to represent English sounds. Meanwhile, Spelling Error defined as an error in the conventionally accepted form of spelling a word (Willet., 2003) This novel is reviewed in the style of a diary written by the main actor himself Charlie. The early parts of the novel contain reports in a ragged style, full of spelling error, punctuation, and grammar mistake because the main actor in this novel has an autism spectrum disorder, so he can not write well and correctly, these things become the characteristic of the autism children that usually they had poor handwritting (Manjiviona., 2005). Therefore in this novel, it can be found that the diary of Charlie contined a lot of errors in terms of spelling, punctuation and grammatical. Then these reports evolved with grammatical improvements, writing styles, and mindsets. At the end of this novel plot, spelling, punctuation and grammatical errors reappear in this novel. The sample of the data that found in this novel:

SL: I said okay and Prof Nemur showed me how to werk the TV that reely wasnt a TV. I askd him what did it do. First, he look sore again because I asked him to explane me and he said I shoud just do what he told me. But Dr Strauss said he shoud explane it to me because I was beginning to questien authorety. I dont no what that meens but Prof Nemur looked like he was going to bite his lip off. Then he explaned me very slow that the mashine did lots of things to my mind. Somethings it did just before I fall asleep like teach me things when Im very sleepy and a little while after I start to fall asleep I still hear the talk even if I dont see the picturs anymore. Other things is at nite its suppose to make me have dreams and remembir things that happened a long time ago when I was a very littel kid. Its scary.

TL: Aku bilang oke dan Prof Nemur memperlihatkan padaku bagaimana TV yang bukan TV sebenarannya itu bekreja. Aku tanya padanya apa gunanya. Pertama-tama ia tumpak cemberut karena aku minta penjlasan padanya dan ia bilang aku hanya harus melakukan apa yang dikatakannya. Tapi Dr Strauss bilang ia harus menjlaskannya padaku karena aku mulai mempertanyakan otoritas. Aku tidak tau apa atrinya tapi Prof Nemur kelihatan seperti akan menggigit putus bibirnya. Lalu ia menjlaskan padaku dengan lambat sekali bahwa mesyin itu bisa melakukan banyak hal pada pikiranku. Sesuatu akan terjadi sebelum aku tertidur seperti mengajariku hal-hal ketika aku sangat mengantuk dan sejenak sebelum aku betul-betul tertidur aku masih bisa mendengar percakapan bahkan ketika aku tidak lagi melihat gambarnya. Hal lainnya terjadi pada malam hari dan akan membuatku bermimpi dan inggat hal-hal yang terjadi pada masa silam ketika aku masih kecil. Menakutkan.

The fragmentation of the novel in both languages indicates the decreasing in the level of acceptability, for example the word 'askd' is meant here is 'asked' which means bertanya in bahasa. However, in its translation it translates to 'tanya' which here seems that the translator eliminates the element of spelling errors in the target language text. Another example found in datum 26 above is the existence of the phrase 'the picturs' which contains ommisions type spelling errors, however this is omitted by the translator in the target language into 'gambarnya' which shows that the translation does not contain any spelling errors at all. In this case it appears that the translator chose to eliminate the misspelling that represents the condition of autism in the main character in this novel. Given the importance of analyzing some words and phrases that represent the condition of authors in this novel, the researcher decided to examine the techniques, methods and ideology of translation and its impact on the quality of translation of words containing misspellings in the novel. 
From this reason, The study has the following aims: to analyze the quality of translation for the words that contain spelling,punctuation and grammatical errors from the accuracy, acceptability, and readability. In order to analyze the quality of translation, related to the accuracy, acceptability and readability, the researcher used the instrument of translation quality assessment from Nababan et al. (2012).

\section{Methodology}

The research method applied is descriptive qualitative. According to Sutopo, in the qualitative research, "the data collected are in the forms of words, sentences or pictures which has meaning rather than number or frequencies" (2002: 35). All of the data on this research are in the form of words. This research belongs to qualitative descriptive method because the process of this research done by collecting data, analyzing data, and writing the result. In addition to that, it is embedded case study. The sources of data consist of documents and informants selected with purposive sampling technique. The documents are Flowers for Algernon Novel and its translation version. The data are the words that contain spelling error, punctuation error, and grammar mistake in Flowers for Algernon novel that have been validated by validator and the information about translation quality given by raters. Informants are validator and three raters. The techniques of collecting data are document analysis, questionnaire, and focus group discussion. The data were analyzed by using ethnography method composed by Spradley (2002). This research is organized in the following procedures: 1) reading Flowers for Algernon novel and its translation and understanding what problems occured in the translation; 2) Collecting the data in the Flowers for Algernon novel that contain spelling, punctuation and grammatical errors; 3) Applying the data coding. Each datum is given number in order to make it easier to analyze; 4) Analyzing the translation techniques; 5) Making a list of data in the form of questionnaire; 6) Distributing questionnaire to the raters; 7) Doing interview with the respondents; 8) Analyzing the data to find out the impacts of the translation techniques toward the quality of the translation in terms of accuracy, acceptability, and readability; 9) Drawing the conclusion.

\section{Results and Discussion}

Assessment of translation quality refers to three components, namely accuracy, acceptability, and readability. This assessment is done by analyzing through the FGD (Focus Group Discussion) process of three raters about the accuracy, acceptability and readability of words and phrases that contain spelling, punctuation and grammatical errors. Assessment of the quality of translation in this study used the scale of translation quality assessment proposed by Nababan, Nuraeni, and Sumardiono (2012).

\section{Accuracy}

The results of 309 data show that the data belonging to accurate translation amounted to 303 data (98.05\%), not found in less accurate data and inaccurate data of 6 data (1.94\%). Accuracy refers to the equivalence between the information in the source language and the information in the target language (Shuttleworth \& Cowie., 1997). Based on the scale of this study, the accuracy is divided into three categories, which are accurate, less accurate and inaccurate. 


\section{a) Accurate Translation}

The results showed that there were 303 data (98.05\%) belonged to accurate translation. It is said to be accurate if a message in the form of an accurate word, phrase, clause or source language sentence is assigned accurately into the target language marked with a context-situation translation and there is no distortion, addition or subtraction of messages. In addition, messages are delivered accurately in the target language.

From this study, found 303 data (98.05\%) categorized as accurate translations consisting of 162 data using established equivalent technique (52.42\%), graphology normalization technique of 127 data (41.1\%), and compensation technique 14 data (4.5\%). Here is an example of accurate data translation findings:

\section{Data 082:}

SL: I dint understand about it but I remembir Dr. Strauss said do anything the testor telld me even if it dont make no sense because thats testing.

TL: Aku tidak mengerti itu tapi aku inggat Dr Strauss bilang aku harus lakukan apa saja yang diprintah penguji padaku walau itu tidak masuk akal karena itu ujian.

The translation above is accurately transferred from the source language, there is no distortion occurs. This is because, the word 'telld' which here contains the Spelling Error type Addition also well represented in the target language to be 'diprintah' which here also contains spelling errors. The function in the source language is well conveyed to the target language. Thus there is no deletion of autism character in that words, all messages conveyed well, therefore the translation is said to be accurate.

\section{b) Less Accurate Translation}

The translation is said to be less accurate if the messages in the form of source language words and phrases are switched less accurately into the target language because the translation is less appropriate for the context of the situation and some words contain multiple or double functions (taxa), the addition and subtraction of messages. The findings show that there is no data found in the less accurate translation category.

\section{c) Not Accurate Translation}

According to the results of the study, the category of inaccurate translation includes 6 data (1.94\%) and this number is derived from deletion techniques. Translation is said to be inaccurate if a message in the form of a word or phrase in the source language is switched inaccurately into the target language because the translation does not fit the context of the situation and there is a distortion of deleted functions and messages; The text of source language is not translated. Here are examples of inaccurate translation data findings: 


\section{Data 047:}

SL: He had a wite coat like a docter but I dont think he was no docter because he dint tell me to opin my mouth and say ah.

TL : Ia pake jas puith seperti doktre karena ia tidak bilang sama aku buka mulut dan bilang aaa....

The example of the data above is an example of inaccurate translation, this is because the translator removes the autism marker element in the sentence, which is the word 'docter', that contains Spelling Error Types Substitution. However this word is removed by translator using deletion technique. Therefore it causes a message in the form of a word that characterizes an autism person in that novel is not conveyed to the reader and also found some distortion meaning and words are omitted causing these translations are categorized as inaccurate.

\section{Acceptability}

Acceptability refers to the conformity of translation to the linguistic and cultural norms of the target language (Nababan, 2013). Based on the assessment scale of acceptability used in this study, acceptability aspect is divided into three categories, namely: acceptable, less acceptable and not acceptable. The results of Focus Group Discussion (FGD) on 309 data indicate that the data belonging to the acceptable translation were 177 data $(57.28 \%)$, less acceptable were 126 data $(40.77 \%)$ and not acceptable were 6 data (1.94\%).

\section{a) Acceptable Translation}

There are 177 data $(57.28 \%)$ which belong to acceptable translation. Translation is said to be acceptable if the translation is sounds natural; the choice of grammar and spelling words and phrases used are in accordance with Indonesian grammatical rule, norms and culture. According to the results of the study, the acceptable translation were found 177 data $(57,28 \%)$ which consisted of 165 data from established equivalent technique (53.39\%) and 12 data from compensation techniques $(3.88 \%)$. Here is an example of acceptable translation data:

\section{Data 054:}

SL: I dint know what he was gonna do and I was holding on tite to the chair like sometimes when I go to a dentist onley Burt aint no dentist neither but he kept telling me to rilax and that gets me skared because it always means its gonna hert.

TL: Aku tidak tahu apa yang akan dilakukannya dan aku pegangan kursi kuwat kuwat seperti waktu aku ke doktre gigi. Namun Burt bukan doktre gigi juga tapi ia terus-terusan bilang padaku untuk santei dan itu malah bikin aku ktakutan karena itu artinya pasti selalu akan syakit.

The translations above are categorized as acceptable translation. This is because the word that contains spelling error type distortion in the source language is the word 'tite', and translated with the same word has a spelling error also in the target language became 'kuwat-kuwat'. In this case the message is delivered well into the target language and the translation also feels natural because it fits within the context in the source language where autism marker elements are maintained in the target language. 


\section{b) Less Acceptable Translation}

In this research there are 126 data $(40,77 \%)$ that categorized as less acceptable. The translation is said to be less acceptable if the translations sound natural, but there are fewer issues where the choice of words, phrases, clauses, sentences, grammar and spelling are used less in accordance with Indonesian grammatical rules, norms and culture. The translation that categorized as less acceptable were 126 data $(40.77 \%)$ which all the data are derived from graphology normalization technique.

\section{Data 027:}

TL: Dr.Strauss says to rite a lot evrything that happins to me but I cant think anymor because I have nothing to rite so I will close for today... yrs truly Charlie Gordon.

SL: Dr Strauss bilang supaya aku sering nulis apa saja yang kupikir dan yang trejadi padaku tapi aku tidak bisa berpikir lagi karena tidak punya bahan untuk ditulsi hari ini jadi akan aku sudahi untuk hari ini...slam hangt Charlie Gordon.

The above data is categorized as less acceptable translation because the word that became the autism marker in the source language ('evrything') does not appear into the target language causing this translation became less acceptable translation. This is because the translation has undergone a change in form from the original one containing spelling errors, however it is made right or be a normal spelling in the target language. Therefore it causes the characterization score of acceptability becomes less.

\section{c) Not Acceptable Translation}

There are 6 data (1.94\%) categorized into not acceptable translation and 6 data are derived from deleted techniques. In this category the definition of unacceptable translation is unnatural translation or feels like the work of translation, the choice of words, phrases, clauses, sentences, grammar and spellings used are inconsistent with Indonesian rules, norms and culture. This is an example of unacceptable translation data:

\section{Data 075:}

Bsu: I thot that was a easy test but when I got up to go Burt stoppd me and said now sit down Charlie we are not thru yet.

Bsa: Aku pikri itu ujian mudah tapi ketika aku berdiri untuk pergi Burt menghnetikan aku dan bilang duduklah Charlie kita belum slesei.

The data is included in the category of unacceptable translation because, the translation is not natural and found grammatical errors in which here grammatical errors are also markers of autism in the source language, but this word is omitted by the translator using the deletion technique. So in this case it causes unacceptable translation. 


\section{Readability}

Readability in translation refers to the extent to which a text is easy to read and understand by the target reader. Based on the assessment instruments of Nababan et al (2012), translations belong into the category of high degree of readability if the word, technical term, phrase, clause, sentence or subtitle can be easily understood by the reader. Based on the scale of the readability assessment used in this study, readability is divided into three categories, namely: high readability, moderate readability, and low readability. The result of Focus Group Discussion (FGD) on 309 data shows that the data belonging to high readability translation is 290 data $(93.85 \%)$, moderate readability data is 13 data $(4.20 \%)$ and low readability is 6 data $(1.94 \%)$.

\section{a) High Readability Translation}

There are 290 data $(93,85 \%)$ that have high readability in this research. Translations belong into the category of high readability if a word, technical term, phrase, clause, sentence or subtitle can be easily understood by the reader. According to the results of the study, the high-translation data found 290 data (93.85\%) consisted of the established equivalent translation technique 149 data (48.2\%), the graphology normalization technique 127 data $(41.10 \%)$ and compensation technique is 14 data $(4,53 \%)$. Here are examples of data translation findings that have a high level of readability:

Here are examples of data translation findings that have a high level of readability:

\section{Data 080:}

SL: I dint understand about it but I remembir Dr Strauss said do anything the testor telld me even if it dont make no sense because thats testing.

TL: Aku tidak mengerti itu tapi aku inggat Dr Strauss bilang aku harus lakukan apa saja yang diprintah penguji padaku walau itu tidak masuk akal karena itu ujian.

The data is data that has high readability because, the word is still easily readable by the reader despite spelling errors. The word 'inggat' in this translation is still felt readable because the readers know the context of the story contained in this novel that tells the condition of an autistic character so that many spelling errors, punctuation and grammatical found in this novel.

\section{b) Moderate Readability Translation}

There are 18 data $(5.82 \%)$ in this study included in the category of moderate readability translation. The moderate readability translation consisted of 16 data from established equivalent technique $(5.17 \%)$, and 2 data from compensation techniques $(0.64 \%)$. Translation is included in the category of moderate readability if generally the translation of words, phrases and technical terms are still sufficiently understood by the reader. Here are examples of data translation findings that have moderate readability:

\section{Data 094:}

Bsu: I holded the card up close and then far away. 
Bsa: Aku penggan kartu itu dekat-dekat lalu jauh-jauh.

The above data is included in the category of being spoken, because the word 'penggan' which is intended to 'pegang' in the target language is still sufficiently understood by the reader, although not too high the level of readability, but the word is still understandable to the reader which means 'grasp'.

\section{c) Low Readability Translation}

There are 6 data (1.94\%) translations in this study included in the category of low legibility of 309 data analyzed. Translations fall into the category of low readability if translation is difficult for the reader to understand. According to the results of the study, the low-translation translation category consisting of 6 data (1.94\%) derived from the technique of translation deletion. Here is an example of a low-reading translation find:

\section{Data 241:}

SL: So I said hello Miss Kinnian I'm redy for my lessen today only I lossed the book we was using.

TL: Maka aku berkata halo Nona Kinnian akusiap untuk blajar hari ini hanya aku khilangan buku yang kami pakai.

The data is included in the category of translation with a low level of readability due to the word 'was' which here is a word that marks the character of autism because it contains grammatical errors omitted by the translator thus causing this translation has a low score of readability.

\section{Translation Quality}

In the previous section has described the overall data for accuracy, acceptability and readability. From the scores of each aspect calculated can be calculated the average score of the three aspects with the weighting system. The weighting system also refers to the theory of Nababan et al. (2012), ie score 3 for accuracy, score 2 for readability, and score 1 for readability. The average score of the three aspects is calculated in Table 4.

The calculation (Table 4) shows that the average score of the three aspects of accuracy, acceptability and readability is 2.81 . Scores in this study illustrate that the overall translation of words and phrases that represent the condition of Autism in the novel Flowers for Algernon can be said to be accurate, acceptable and easily understood by the target readers.

Table 4 Translation Quality

\begin{tabular}{ccccc}
\hline \multicolumn{5}{c}{ Average Score } \\
\hline Accuracy (a) & Acceptability (b) & Readability (c) & Total (d) & Average Score \\
Ka x 3 & Kb x 2 & Kt x 1 & $\mathrm{a}+\mathrm{b}+\mathrm{c}$ & $\mathrm{d}: 6$ \\
\hline
\end{tabular}


In this research, there are 309 data, 303 data are translated accurately, there is no data is translated with less accurate, and 6 data are translated not accurately. In terms of acceptance, 177 data received in the category of acceptable, 126 data entered in the category of less acceptable and 6 data entered in the category of not acceptable. Then in terms of readability obtained 290 data categorized in the category of high-readability, 18 data entered in the category of moderate readability and 6 data entered into the category of low readability translation.

Calculation of the average score of the three aspects of accuracy, acceptability and readability is divided into three aspect, for score of accuracy is 2.96 , acceptability score is 2.55 and readability score is 2.9 so the average score analyzed in this study is 2.8175 . Scores in this study illustrate that the overall translation of words and phrases that contain spelling, punctuation and grammar errors in Flowers for Algernon novel can be said to be accurate, acceptable and easily understood by the target audience.

\begin{tabular}{llllll}
\hline Translation & $\sum$ & $\%$ & Accuracy & Acceptability & Readability \\
\hline
\end{tabular}

Tabel 5 Translation technique and translation quality 


\begin{tabular}{|c|c|c|c|c|c|c|c|c|c|c|c|}
\hline Techniques & & & A & LA & NA & A & LA & NA & $\mathrm{H}$ & M & $\mathrm{L}$ \\
\hline Padanan & 162 & 52,42 & 162 & -- & -- & 162 & -- & -- & 149 & 13 & -- \\
\hline Lazim & & $\%$ & & & & & & & & & \\
\hline Graphology & 127 & 41,10 & 127 & -- & -- & -- & 127 & - & 127 & -- & -- \\
\hline Normalization & & $\%$ & & & & & & & & & \\
\hline Kompensasi & 14 & $4,53 \%$ & 14 & -- & -- & 14 & -- & -- & 14 & -- & -- \\
\hline Delesi & 6 & $1,94 \%$ & -- & -- & 6 & -- & -- & 6 & -- & -- & 6 \\
\hline
\end{tabular}

This study shows that translation quality assessment by expert readers and target readers has the same projection. This proved the score of high accuracy, acceptability and readability, resulting in high quality translation scores as well (2.81). This high quality translation score shows that the quality of the translations in words and phrases that contain spelling, punctuation and grammar errors in Flowers for Algernon novel is indeed not perfect but based on this research has good quality.

The three aspects of high quality translation can be achieved because the ideology, methodology and techniques are used appropriately and have various variants, so that the functional distortion can be avoided, easily understood, and acceptable in the rules of the target language as well has been adapted to the context of the story in the novel. So that does not cause a shift in the main character's in the novel. This is proven through the techniques applied to the quality of translation, namely: established equivalent technique is 162 data, graphology normalization technique is 127 data, and compensation technique is 14 data, and deletion technique is 6 data.

\section{Conclusion}

From 309 words and phrases contained in this novel, 303 data $(98.05 \%)$ are categorized as accurate translation and 6 data (1.94\%) are categorized not accurate. For the acceptability aspect, 177 data $(57.28 \%)$ are categorized as acceptable translation, 126 data $(40.77 \%)$ are categorized as less acceptable and 6 data (1.94\%) are categorized as not acceptable. While the readability aspect of 285 data (92.23\%), has high readability level, 18 data (5.82\%) have moderate readability level and 6 data (1,94\%) have low level of readability. The average score of the three aspects of accuracy, acceptability and readability is 2.81.From the 309 data found data that has a low readability of 6 data, this is because the translator applied a deletion technique which eliminates the element of autism character marker in the novel that causes low readability. In this study the application of established equivalent techniques dominates in almost all word translations that contain spelling, punctuation and grammatical errors. The application of the translation technique contributes positively to the quality of the translation in its accuracy, acceptability and readability.

The average score of 309 word and phrase data analyzed in this study is 2.8 which illustrates that the overall translation of words and phrases representing the condition of Autism in this novel can be said to be accurate, acceptable and easily understood by the target audience. This study shows that translation quality assessment by expert readers and target readers has the same projection. This proved the score of accuracy, acceptability and high readability, resulting in high quality translation scores as well. This high 
quality translation score indicates that the quality of word and phrase translation that represents the condition of Autism Spectrum Disorder character on Flowers for Algernon novel is not perfect but based on this research has good quality.

\section{Suggestion}

The translator of this novel would be better if she was more consistent in noticing the word marker of Autism when translated in Bahasa Indonesia as the target language and keeping an eye on the word choice used in the translation for the accuracy, acceptability and readability of the word to be improved. The important thing to note here is this novel included in the novel Science Fiction which in this novel tells the condition of someone who suffered from Autism so that many found spelling mistakes, punctuation and grammar for it is appropriate that the mistakes contained in the source language is also should appear in the target language. All information in the source language text is an important component of a text. Therefore, the reduction, omission or non-translation of information may affect the quality of the translation, so the application of the deletion technique should be carried out with good judgment.The translator should consider the context of the story in this novel better, since characterization is an important element in a novel, then the use of graphology normalization translation techniques in this case causes the translation to be less acceptable. The use of graphology normalization techniques causes the authors' marking elements in this novel to be lost. So it is better that the authors of the authors are presented in the target language, so the elements of acceptance in this translation can be high.This research is product-oriented, that is identifying the type of spelling, punctuation and grammatical errors found in the novel Flowers for Algernon. By using the same data source, it is necessary to do advanced research oriented to the translation process in this novel.

\section{References}

Akbari, M. (2012). Structural Shifts in Translation of Children's Literature. International Journal of Linguistics, 4(2). ISSN 1948-5425.

Akhadiah. (1990). Pembinaan Kemampuan Menulis Bahasa Indonesia. Jakarta: Erlangga. American Psychiatrie Association. 1994. Diagnostic and Statistical Manual of Mental Disorders, Fourth Edition, Washington, DC: APA. DSM-IV.

Bailey, Eileen. (2011). Asperger Syndrome. Matrix Parent Network and Resource Center. Autismhelp.org.

Baker, M. (2006). Translation and Conflict: A Narrative Account, London \& New York: Routledge.

Bartolucci, G., Pierce, S. and Streiner, D. (1980). Cross-Sectional Studies of Grammatical Morphemes in Autistic and Mentally Retarded Children. Journal of Autism and Developmental Disorders, 10: 39-50. [Crossref], [PubMed], [Web of Science $\left.{ }^{\circledR}\right]$.

Bastian, Amy. (2007). Autism and Motor Skills: A Matter of White Matter?.Journal of Neurology 47(4): 448-460. 
Benjamin, J. (2002). Exploring Natural Language: Working with the British component of The International Corpus of English. UCL: London Press.

Bloomfield, T.M. (1967). Apeak Shift on a Line tilt-Continuum. Journal of The Experimental Analysis of Autism Behavior, 10: 361-366.

Bowen, L. P. (2002) Social Skills and Autistic Spectrum Disorders, Paul Chapman Publishing, London, 2007.

Brann, B. (1997). The Brann analysis grid for spelling. Australia P. J. Developments.

Cantwell, D. P., Baker, L., Mattison, R. E. (1979). The Prevalence of Psychiatric Disorder in Children with Speech and Language Disorder: An epidiomologic study, Journal of The American Academy of Child Psychiatry, 18: 450-461.

Catford, J. C. (1965). A Linguistic Theory of Translation. Oxford: Oxford University Press.

Chaer, Abdul. (2009). Psikolinguistik Kajian Teoritik. Jakarta: Rineka Cipta.

Christie, Phil. (2009). Langkah Awal Berinteraksi Dengan Anak Autis. Jakarta: Gramedia Pustaka Utama.

Cook, V. (2014). The English writing system. Taylor \& Francis.

Cook, V. J. (1999). Teaching spelling. Retrieved from http://privatewww.essex.ac.uk/ vcook/OBS2O .html.

Duchan, F. J. (2006). The Early Years of Language, Speech, and Hearing Services in US Schools. Researchgate.

Fay, L. (1971). Reading and spelling: How are they related?.ERIC Document Reproduction Service No. ED059009.

Flood, A. (2014). Flowers for Algernon's Sad, Sweet Genius. (https://www.theguardian.com/ books/booksblog/2014/jun18/flowers-for-algernon-genius-daniel-keyes).

Gillingham, G. (1995). Autism Handle with Care! Understanding and Managing Behavior of Children and Adults with Autism. Future Education Inc., Arlington.

Giri, A. (2010). Errors in the Use of English Grammar. Journal of NELTA. 15/1-2, 54-63.

Hasibuan, R. S. (1991). Teori Terjemahan dan Kaitannya Dengan tata bahasa Inggris. Jakarta: Dian Rakyat.

Heward, W. L. (2006). Review of Disability Studies. International Journal Volume II Issue 1. Copyright 2006, All Rights Reserved by the Center on Disability Studies University of Hawaii at Manoa, Honolulu, Hawaii, U.S.A.

Hoed, Benny. (2006). Penerjemahan dan Kebudayaan. Pustaka Jaya. 
Hosseini.S.M. (2011). "An Analysis of Culture-specific Items in the Persian Translation of "Dubliners" Based on Newmark's Mode". ISSN 1799-2591 Theory and Practice in Language Studies, Vol. 1, No. 12, pp. 1767-1779, December 2011 @ 2011 ACADEMY PUBLISHER Manufactured in Finland.

Ida, F. (2006). English Spelling in Swedish Secondary School: Students' Attitudes and Performance. Karlstads University.

Kanner, L. (1968). Autistic Disturbances of Affective Contact. Nerv Child 2: 217- 50. "Reprint". Acta Paedopsychiatr 35(4): 100-36.

Kridalaksana, Harimurti. (2008). Kamus Linguistik. Edisi Keempat. Jakarta: PT Gramedia Pustaka Utama.

Kusumayani, A. (2013). “Teknik Penerjemahan Istilah Tabu dalam Film "The Hurt Locker" dan Pengantarnya Terhadap Kualitas Terjemahan”. Jurnal UNS.

Larson, Mildred L. (1998). Meaning-based Translation: A Guide to Cross Language Equivalence (second edition). Lanham: University Press of America.

Lincoln, YS. \& Guba, EG. (1985). Naturalistic Inquiry. Newbury Park, CA: Sage Publications.

Malmkjaer, K. (2005). Linguistics and the Language of Translation (9th ed.). Edinburgh: University Press Ltd. p. 24-30.

Manjiviona, P. (2005). Handwriting of Eight-Year-Old Children with Autistic Spectrum Disorder. Journal of Occupational Therapi, School, and Early Intervention.

Moleong, L. J. (2010). Metodologi Penelitian Kualitatif, Bandung: Remaja Rosda karya.

Moseley, D. (1993). How Lack of Confidence in Spelling Affects Children's Written Expression. Wellington, New Zealand: New Zealand Council for Educational Research.

Nababan, M. R. (2003). Teori Menerjemahkan Bahasa Inggris. Yogyakarta: Pustaka Pelajar . (2007). Aspek Genetik, Objektif, dan Afektif dalam Penelitian Penerjemahan. Surakarta: Universitas Sebelas Maret.

. (2008). Teori Menerjemah Bahasa Inggris. Yogyakarta: Pustaka Pelajar.

. (2010). Teknik-Teknik Penerjemahan teks. Unpublished paper presented in National Seminar of Translation in Universitas Widya Mandala Madiun.

Ardiana.N, \& Sumardiono. (2012). Pengembangan Model Penilaian Kualitas Terjemahan. Jurnal Kajian Linguistik dan Sastra, 24(1) :39-57. Surakarta: Universitas Sebelas Maret.

Neubert, A. (2004). Case Studies in Translation: The Study of Translation." A paper presented on across language and culture 5(1): 5-21.

Newmark, P. (1981). Approaches to Translation. Oxford: Pergarmon Press. (1988). A textbook of Translation. London: Prentice Hall. 
Nida, E. (1991). Theories of Translation. TTR: Traduction, Terminologie, Rédaction, 4(1): 19-32. doi:10.7202/037079ar.

Routledge.

(2000). Principles of Correspondence. In the Translation Studies Reader, 126-140. London:

Nida, E. A., \& Taber, C. R. (1974). The Theory and Practice of Translation. Leiden: Published for the United Bible Societies by E.J. Brill.

. (1982). The Theory and Practice of Translation. Leiden: E. J. Brill.

Nord, C. (2005). Text Analysis in Translation: Theory, Methodology, and Didactic Application of a Model for Translation-Oriented Text Analysis. Amsterdam/ New York, NY: Rodopi.

Novalinda. (2011). Analisis Teknik, Metode, Ideologi dan Kualitas Terjemahan Cerita anak Serial Erlangga for kids. Jurnal UNS.

Nurdiantoro, Burhan. (1991). Teori Pengkajian Fiksi. Yogyakarta: Gadjah Mada University Press.

Reed, L.V. S. (2009). Teaching Young Students with autism to Write. Wichita State University, Pensylvania USA.

Retnomurti, Ayu Bandi and Indiyah Imran (n.d.). The Equivalence and Shift in the English Translation of Indonesian Noun Phrases. Universitas Gunadarma Jl. Margonda Raya no: 100 Depok.

Rezvani. R (2014). An Evaluation of Translation Quality Assessment Course: Voices from Instructors. International Conference on Current Trends in ELT.

Santosa, R. (2003). Semiotika Sosial: Pandangan Terhadap Bahasa (Social Semiotics: Perspective on Language). Surabaya: Pustaka Eureka dan Jawa Pos Press.

. (2017). Buku Metode Penelitian Kualitatif Kebahasaan. Solo: UNS press.

Shuttleworth, M \& Cowie, M. (1997). Dictionary of Translation Studies. Manchester, St. Jerome. Publishing, 1997.

Slobin, D. I. (1974). Psycholinguistics. Glenview, IL: Scott, Foresman and Company.

Smedley, D. (1983). Teaching the basic skills: Spelling, punctuation and grammar in secondary English. London: Methuen.

Spradley, James.P. (1979). Etnographic Interview. Fort Worth, Tex.: Harcourt Brace Jovanovich College Publishers.

Sterling, Bruce. (2016). Science Fiction, Literature and Performance. Encyclopedia Britannica Press. London.

Subyantoro. (2012). Peningkatan Efektifitas Pembelajaran Anak Autis melalui Implementasi Pendekatan Individualized Education Program (IEP) di SDN Inklusif Klampis Ngasem.Surabaya: Airlangga University Press. 
Suryana, A. (2004). Terapi Autisme, anak Berbakat dan anak Hiperaktif. Jakarta: Progres Jakarta.

Sutopo, A. (2002). Metodologi Penelitian Kualitatif. Surakarta: UNS Press.

. (2016). Model Penilaian Kualitas Terjemahan Karya Sastra. ISSN 2407-9189. The 4th University Research Coloquium 2016.

Widdowson, Henry. (2004). Text, Context, and Pretext. International Journal of Applied Linguistic.

Wilkinson, David. (2000). The Researcher's Toolkit. London: Cambridge University.

Willett, L. (2003). Using spelling data to improve students-learning outcomes: More than just numbers. Australia-Queensland Studies.

Zuliani. R (2011). Teknik Penerjemahan dan Kualitas Terjemahan Ungkapan Budaya dalam Novel The Kite Runner karya Khaled Hosseini. UNS Press.

\section{Internet}

https://www.theguardian.com/books/booksblog/2014/jun18/flowers-for-algernon-genius-daniel-keyes (diakses pada 5 November 2017).

\section{Copyrights}

Copyright for this article is retained by the author(s), with first publication rights granted to the journal.

This is an open-access article distributed under the terms and conditions of the Creative Commons Attribution license (http://creativecommons.org/licenses/by/4.0/). 